\title{
Heterologous Secretory Expression and Characterization of Dimerized Bone Morphogenetic Protein 2 in Bacillus subtilis
}

\author{
Muhammad Umair Hanif,' Roquyya Gul,' \\ Muhammad Imran Hanif, ${ }^{2}$ and Abid Ali Hashmi ${ }^{2}$ \\ ${ }^{1}$ Institute of Molecular Biology and Biotechnology/Centre for Research in Molecular Medicine, The University of Lahore, \\ 1-Km Defense Road, Bhubtian Chowk, Lahore, Pakistan \\ ${ }^{2}$ Gulab Devi Educational Complex, Gulab Devi Chest Hospital, Ferozpur Road, Lahore, Pakistan \\ Correspondence should be addressed to Roquyya Gul; ruqayya.gul@imbb.uol.edu.pk
}

Received 11 September 2017; Revised 12 October 2017; Accepted 30 October 2017; Published 23 November 2017

Academic Editor: Yun-Peng Chao

Copyright (c) 2017 Muhammad Umair Hanif et al. This is an open access article distributed under the Creative Commons Attribution License, which permits unrestricted use, distribution, and reproduction in any medium, provided the original work is properly cited.

\begin{abstract}
Recombinant human Bone Morphogenetic Protein 2 (rhBMP2) has important applications in the spine fusion and ortho/maxillofacial surgeries. Here we first report the secretory expression of biological active dimerized rhBMP2 from Bacillus subtilis system. The mature domain of BMP2 gene was amplified from pTz57R/BMP2 plasmid. By using pHT43 expression vector two constructs, pHT43-BMP2-M (single BMP2 gene) and pHT43-BMP2-D (two BMP2 genes coupled with a linker to produce a dimer), were designed. After primary cloning (DH5 $\alpha$ strain) and sequence analysis, constructs were transformed into Bacillus subtilis for secretory expression. Expression conditions like media $(2 \mathrm{xYT})$ and temperature $\left(30^{\circ} \mathrm{C}\right)$ were optimized. Maximum $35 \%$ and $25 \%$ secretory expression of monomer $(\sim 13 \mathrm{kDa})$ and dimer $(\sim 25 \mathrm{kDa})$, respectively, were observed on SDS-PAGE in SCK6 strain. The expression and dimeric nature of rhBMP2 were confirmed by western blot and native PAGE analysis. For rhBMP2 purification, $200 \mathrm{ml}$ culture supernatant was freeze dried to $10 \mathrm{ml}$ and dialyzed (Tris- $\mathrm{Cl}, \mathrm{pH}$ 8.5) and Fast Protein Liquid Chromatography (6 ml, Resource Q column) was performed. The rhBMP2 monomer and dimer were eluted at $0.9 \mathrm{M}$ and $0.6 \mathrm{M} \mathrm{NaCl}$, respectively. The alkaline phosphatase assay of rhBMP2 $(0,50,100,200$, and $400 \mathrm{ng} / \mathrm{ml})$ was analyzed on $\mathrm{C} 2 \mathrm{C} 12$ cells and maximum $200 \mathrm{ng} / \mathrm{ml}$ activity was observed in dose dependent manner.
\end{abstract}

\section{Introduction}

Bone Morphogenetic Proteins (BMPs) are the members of the TGF- $\beta$ superfamily and act as regulators during embryogenesis, bone, and cartilage repair [1]. Over 20 different members of the BMP subfamily had been identified and characterized to date in humans [2]. BMP binds through type I and type II serine/threonine kinase receptors and SMAD intracellular signaling pathway to regulate various biological processes [3]. Two members of this family, BMP2 and BMP-7, had been approved by FDA as recombinant human proteins for clinical use and proved their significance in clinical orthopedic studies [1] and in oral/maxillofacial surgeries [4]. Generally BMPs are active in very low doses (5-20 ng/ml) but commercially available rhBMPs are used in very high doses (up to $40 \mathrm{mg}$ ) in some procedures [5].
Therefore, cost effect bulk production of rhBMP is mandatory for the therapeutic applications.

To date BMPs and other members of the TGF $\beta$ family have been produced in various expression systems, mainly bacterial [6], yeast [7], and mammalian [8]. The mammalian expression system has the advantage of biologically active production of heterologous proteins but the manufacturing cost is high with low yield of protein recovery; also the system is difficult to scale up for the commercial production. In bacterial expression system, $E$. coli is the most widely used recombinant host but despite its cost effectiveness and ability to produce large quantities of heterologous proteins, it has a drawback that most proteins are produced in biologically inactive state with no posttranslational modifications [9]. Generally release of intracellular protein and in vitro refolding step is required to produce biological active proteins 
TABLE 1: Comparison of different recombinant human proteins produced in Bacillus species.

\begin{tabular}{|c|c|c|c|c|c|}
\hline Recombinant human proteins & Vector & Media & Yield & Species & Reference \\
\hline Epidermal Growth Factor & pM2Veg & LB & $7.0 \mathrm{mg} / \mathrm{L}$ & B. subtilis & [19] \\
\hline Interferon- $\alpha 2$ & pKTH68 & Broth-starch Medium & $0.5-1.0 \mathrm{mg} / \mathrm{L}$ & B. subtilis & [20] \\
\hline Interleukin 3 & pMA5 derivatives & 2X YT, MXR, MSR & $100 \mu \mathrm{g}-100 \mathrm{mg} / \mathrm{L}$ & B. subtilis & [16] \\
\hline Granulocyte Colony Stimulating Factor & pNWPH & 2X L-MAL & $96 \mathrm{mg} / \mathrm{L}$ & B. subtilis & [18] \\
\hline Proinsulin & pSubP14 & Mineral medium (MMG) & $1000 \mathrm{mg} / \mathrm{L}$ & B. subtilis & {$[21]$} \\
\hline BMP7 & pBPT62 & LBL & $350 \mathrm{ng} / \mathrm{L}$ & B. subtilis & [15] \\
\hline Interleukin 2 & pNU211 & $3 \mathrm{PY}$ & $120 \mathrm{mg} / \mathrm{L}$ & B. brevis & [17] \\
\hline rhBMP2 & pHT43 & $2 \mathrm{X} \mathrm{YT}$ & $5-9 \mathrm{mg} / \mathrm{L}$ & B. subtilis & Current study \\
\hline
\end{tabular}

TABLE 2: Sequence of hBMP2 monomer and dimer primers showing nucleotide and amplicon size (bp). The bold and underline sequences show restriction sites and His-tag $\left(3^{\prime}\right)$, respectively, incorporated in the primers.

\begin{tabular}{|c|c|c|c|}
\hline Set of primers & Sequence $\left(5^{\prime}-3^{\prime}\right)$ & $\begin{array}{l}\text { Nucleotide } \\
\quad(\mathrm{bp})\end{array}$ & $\begin{array}{l}\text { Amplicon } \\
\text { size (bp) }\end{array}$ \\
\hline FBMP2-M & CTATGCTTAGCAGGGGGATCCCAAGCCAAACACAAAC & 37 & \multirow{3}{*}{399} \\
\hline & BamHI & & \\
\hline RBMP2-M & $\frac{\text { TCTAGATTAATGGTGGTGGTGATGATGACCGCGACCGCGACACCCACAACCCTC }}{X b a \mathrm{I}}$ & 54 & \\
\hline FBMP2-D & CTATGCTTAGCAGGGGGATCC & 21 & \multirow[b]{2}{*}{384} \\
\hline RBMP-L & $\begin{array}{c}\text { AGATCTACTACCTGAACTACTGCGACACCCACAACCCTCC } \\
B g l I I\end{array}$ & 40 & \\
\hline FBMP-L & $\begin{array}{l}\text { AGATCTTCAGGTTCGTCTAGTGGTCAAGCCAAACACAAAC } \\
\qquad B g l I I\end{array}$ & 40 & \multirow{2}{*}{402} \\
\hline RBMP2-D & 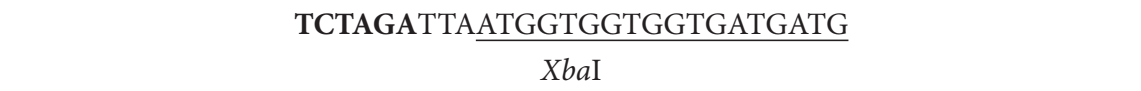 & 27 & \\
\hline
\end{tabular}

which increases the cost and reduces the protein recovery as protein is lost with additional processing. Other useful bacterial system is gram positive soil bacteria, Bacillus subtilis (B. subtilis), which has been known to secrete industrially relevant proteins directly into the culture media with no endo or exotoxins and has the status of GRAS (Generally Recognized as Safe) by US FDA [10]. Over the years many attempts are made and a large number of patents had been filed related to optimization of protein secretion by $B$. subtilis [11], although the secretion of homologous proteins from $B$. subtilis is straightforward with concentrations up to grams per liter [12], while the production of heterologous proteins is problematic and the optimization strategies for overexpression for one protein do not always work for the other proteins [11]. In short the optimization steps and protein quantities vary with the characteristics of the protein under study. Previously secretion of several homologous enzymes and industrial agents including nucleotides, vitamin riboflavin, and flavoring agents has been achieved [13, 14]. Regarding the heterologous secretion of proteins in different Bacillus species generally and especially in the class of cytokines BMP7, interleukin-2 (IL-2), IL-3, and Granulocyte Colony Stimulating Factor (GCSF) had successfully been produced in biologically active form with varying concentrations and purity [15-18] as shown in Table 1.

Considering the advantages of Bacillus expression system, the focus of the present study was to increase the yield of the secretory dimerized rhBMP2, its optimization, and characterization which has not been reported yet.

\section{Materials and Methods}

2.1. Bacterial Strains, Plasmids, and Cloning. E. coli strain; DH5 $\alpha$ and B. subtilis strains; SCK6 and WB600 were used for cloning, subcloning, and rhBMP2 production, respectively. T/A cloning kit (InsTAclone catalog number K1213) containing the pTz57R/T plasmid was purchased from Thermo Scientific. pHT43 (catalog number PBS002) Bacillus expression vector was purchased from MoBiTec GmbH Germany. All the restriction enzymes were purchased from Thermo Scientific unless otherwise specified.

Human BMP2 gene was amplified from pTz57R/BMP2 plasmid (previously constructed in lab) with forward (FBMP2-M) and reverse (RBMP2-M) primers containing restriction sites $(B a m \mathrm{HI} / \mathrm{Xba \textrm {I }})$ and His-tag sequence at $3^{\prime}$ terminal (Table 2). The amplified product was run 
on $1 \%$ agarose and the specific band was eluted and cloned in $\mathrm{pTz} 57 \mathrm{R} / \mathrm{T}$ vector and transformed into $\mathrm{DH} 5 \alpha$ to construct BMP monomer (pTz57R/BMP2-monomer). For the construction of BMP2 homodimer covalently coupled glycine serine rich linker (glycine $_{3}$ serine $\left._{1}\right)_{3}$ along with BglII restriction site was incorporated. Human homodimer BMP2 gene was amplified with two different sets of primers (FBMP2-D/RBMP2-L and FBMP2-L/RBMP2-D) to generate two monomers as described above containing the restriction sites, linker sequence, and the His-tag at the $3^{\prime}$ end of the gene as shown in Table 2. Both the monomers of BMP2 were run on $1 \%$ agarose gel and specific bands were eluted out, cloned in pTz57R/T, and transformed into $\mathrm{DH} 5 \alpha$. To produce homodimer, both the monomers were first amplified, T/A cloned, and digested with BglII. Further, the two digested monomers were ligated by using T4 ligase and then amplified with FBMP2-D and RBMP2-D primers. The product was run on $1 \%$ agarose gel, cloned into pTz57R/T (pTz57R/BMP2Dimer) and transformed in DH5 $\alpha$ as described for the BMP2 monomer. Covalently linked BMP2 homodimer was referred to as BMP2 dimer and the single gene was referred to as BMP2 monomer in this work hereafter. Both constructs (pTz57R/BMP2-monomer and pTz57R/BMP2-dimer) were sequence analyzed for the confirmation of the sequence. The positive transformants were restricted with $\mathrm{BamHI} / \mathrm{Xba \textrm {I }}$ and ligated into properly restricted pHT43 Bacillus expression vector. The plasmids for rhBMP2 production (pHT43BMP2-M and pHT43-BMP2-D) were transformed into $B$. subtilis SCK6 and WB600 strains as essentially described earlier [22, 23].

2.2. Expression and Optimization of rhBMP2. A single positive transformant of each pHT43-BMP2-M and pHT43BMP2-D plasmid was inoculated into $5 \mathrm{ml} \mathrm{LB}$ medium $(5 \mathrm{~g} / \mathrm{L}$ yeast extract, $10 \mathrm{~g} / \mathrm{L}$ tryptone and $10 \mathrm{~g} / \mathrm{L} \mathrm{NaCl}$ ) containing $5 \mu \mathrm{g} / \mathrm{ml}$ chloramphenicol and incubated at $37^{\circ} \mathrm{C}, 200 \mathrm{rpm}$ for overnight. Next morning, $25 \mathrm{ml} \mathrm{LB}$ medium was refreshed with $2 \%$ overnight culture and incubated under the conditions mentioned above until the OD600 reached 0.6-0.8. IPTG $(1 \mathrm{mM})$ was induced to obtain the expression of the rhBMP2 monomer and dimer. A postinduction sample was taken at 2, 4, and 6 hours and cells were harvested by centrifugation at $13000 \mathrm{rpm}$ for $5 \mathrm{~min}$ at $4^{\circ} \mathrm{C}$. The culture supernatant was processed further for the confirmation of secretory protein expression with trichloroacetic acid (TCA) precipitation. Briefly $0.15 \%$ sodium deoxycholate was added in the culture medium and incubated at room temperature for $15 \mathrm{~min}$. After that $150 \mu \mathrm{l}$ of $100 \%$ TCA solution was added and incubated for $10 \mathrm{~min}$ on ice. The sample was then centrifuged at $14000 \mathrm{rpm}$ at $4^{\circ} \mathrm{C}$ for $10 \mathrm{~min}$. The supernatant was discarded and the pellet was washed with $1 \mathrm{ml}$ of $100 \%$ acetone solution twice and centrifuged at $14000 \mathrm{rpm}$ for $10 \mathrm{~min}$ at $4^{\circ} \mathrm{C}$ during washing. The pellet was resuspended in $100 \mu \mathrm{l}$ of Tris-Cl buffer ( $\mathrm{pH}$ 8.0) and run on 18\% SDS-PAGE for expression analysis. After confirmation, the maximum expression of rhBMP2 monomer protein was optimized in three different media [LB, 2xYT (16g/L tryptone, $5 \mathrm{~g} / \mathrm{L}$ $\mathrm{NaCl}, 10 \mathrm{~g} / \mathrm{L}$ yeast extract) and 2xL MAL (2\% tryptone, $1 \%$ yeast extract, $1 \% \mathrm{NaCl}, 7.5 \%$ maltose hydrate, and $7.5 \mu \mathrm{g} / \mathrm{mL}$
MnSO4)] and at two different temperatures, that is, $30^{\circ} \mathrm{C}$ and $37^{\circ} \mathrm{C}$ in SCK6 and WB600 strains. The optimization of rhBMP2 monomer was done initially and then the dimer was grown on the preoptimized conditions of media, temperature, and the strain. Though, monomer and dimer were optimized individually in case of time span, IPTG, and lactose concentration.

2.3. Western Blot, Native PAGE, and Purification of rhBMP2. For western blot analysis, protein samples were run on $18 \%$ SDS-PAGE. After running of the gel, proteins were blotted on to presoaked nitrocellulose membrane by electroblotting using the transfer buffer [ $25 \mathrm{mM}$ Tris, $192 \mathrm{mM}$ glycine, and $6.20 \% \mathrm{v} / \mathrm{v}$ methanol $(\mathrm{pH}$ 8.3)] and run on $400 \mathrm{~mA}$ for 2.5 hours. Membrane was presoaked with $1 \mathrm{x}$ PBST $[\mathrm{NaCl}$ $3.0 \mathrm{gm}, \mathrm{KH}_{2} \mathrm{PO}_{4} 0.2 \mathrm{gm}, \mathrm{NaHPO} 41.15 \mathrm{gm}$, and $\mathrm{KCl} 0.2 \mathrm{gm} / \mathrm{L}$, (pH 7.4) containing 0.5\% Tween-20] and blocking was done with blocking buffer [5\% skimmed milk powder in 1x PBS $\left(\mathrm{NaCl} 3.0 \mathrm{gm}, \mathrm{KH}_{2} \mathrm{PO}_{4} 0.2 \mathrm{gm}, \mathrm{NaHPO} 41.15 \mathrm{gm}\right.$, and $\mathrm{KCl}$ $0.2 \mathrm{gm} / \mathrm{L}, \mathrm{pH} 7.4)]$ and incubated for overnight at $4^{\circ} \mathrm{C}$. The blocked membrane was washed with 1x PBS three times for 15 min each. Anti-human BMP2 antibody (Sino Biological catalog number 10426-MM03) at dilution of 1:500 specific to target protein was incubated with the membrane at room temperature for 2 hours. After washing of unbound primary antibody with $1 \mathrm{x}$ PBST the secondary antibody (goat polyclonal Ab to mouse IgG HRP; lot number GR1293151) at 1:1000 dilution was added at room temperature for 2 hours. Protein was detected by $3,3^{\prime}, 5,5^{\prime}$ tetramethylbenzidine (TMB) substrate (Invitrogen), and reaction was stopped by $1 \mathrm{M} \mathrm{H}_{2} \mathrm{SO}_{4}$. Moreover, to confirm the dimeric form of the rhBMP2 protein $12 \%$ native PAGE was performed in nonreducing condition (without SDS and $\beta$-mercaptoethanol). The samples were neither boiled nor was SDS added in running buffer to maintain the native confirmation and structure of the protein.

The purification of rhBMP2 monomer and dimer proteins were performed in three steps. First a $200 \mathrm{ml}$ of the culture supernatant was freeze dried to a final volume of $10 \mathrm{ml}$ and then dialyzed against the Tris- $\mathrm{Cl}(\mathrm{pH}$ 8.5). Then the proteins were purified using Hi-Trap $6 \mathrm{ml}$ Resource Q column (GE Healthcare) using FPLC system (AKTA purifier GE Healthcare systems). A concentration gradient of $\mathrm{NaCl}$ was used to phase separate the proteins on the basis of ionic strength.

2.4. Biological Activity of rhBMP2. The biological activity of the rhBMP2 monomer and dimer proteins were determined on $\mathrm{C} 2 \mathrm{C} 12$ cells by alkaline phosphatase (ALP) assay (catalog number ab83369 Abcam) in vitro. The cells were grown in complete Dulbecco's Modified Eagle Medium (DMEM) supplemented with $100 \mu \mathrm{g} / \mathrm{ml}$ penicillin, $100 \mathrm{U} / \mathrm{ml}$ streptomycin, and $10 \%$ Fetal Bovine Serum (FBS) at $37^{\circ} \mathrm{C}$ and $5 \% \mathrm{CO}_{2} .1 \times$ $10^{5}$ cells were seeded in the six-well plate and on reaching $\sim 80 \%$ confluency, 24 hours prior to experiment, and cells were serum starved with DMEM medium containing $2 \%$ FBS. Purified rhBMP2 monomer and dimer were induced at $0,50,100,200$, and $400 \mathrm{ng} / \mathrm{ml}$ in DMEM medium without FBS. Commercially available rhBMP2 (SinoBiological catalog 


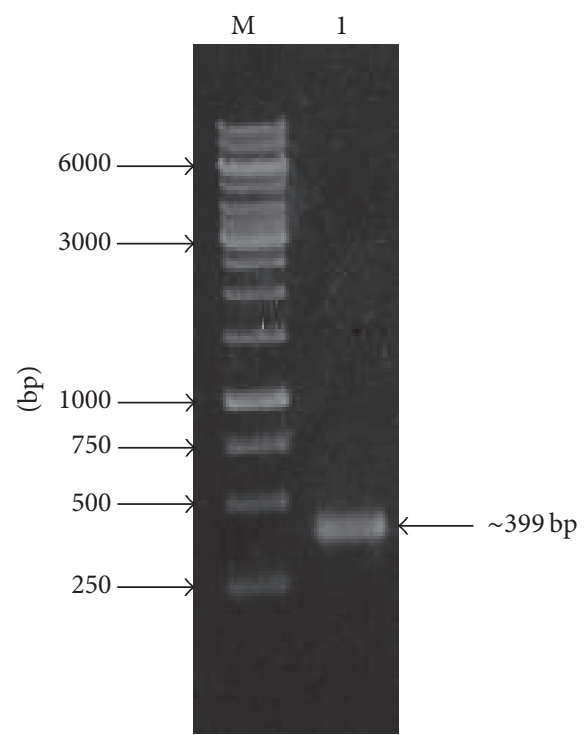

(a)

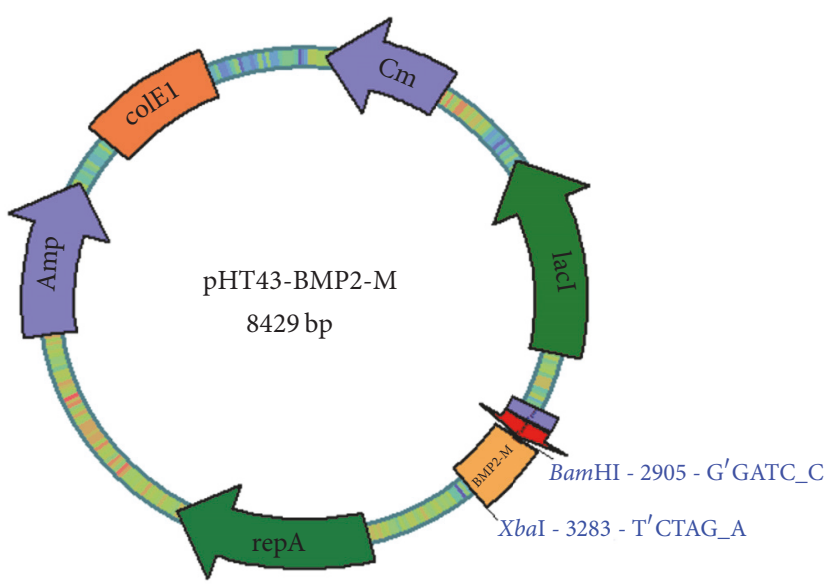

(c)

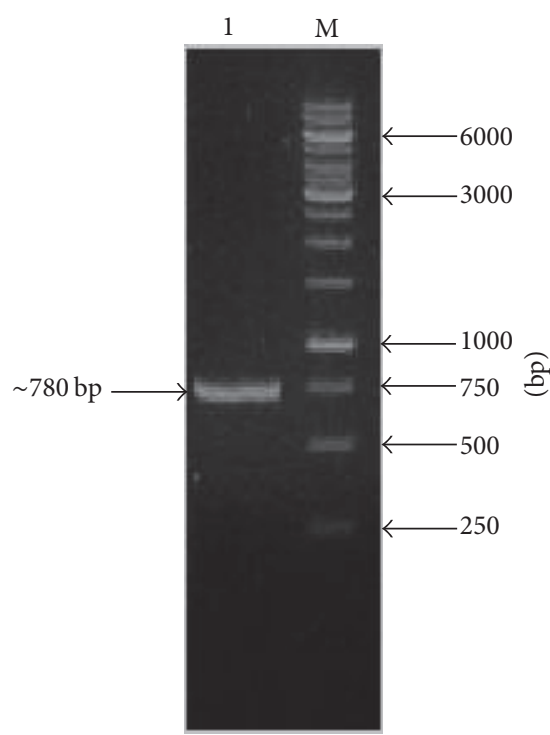

(b)

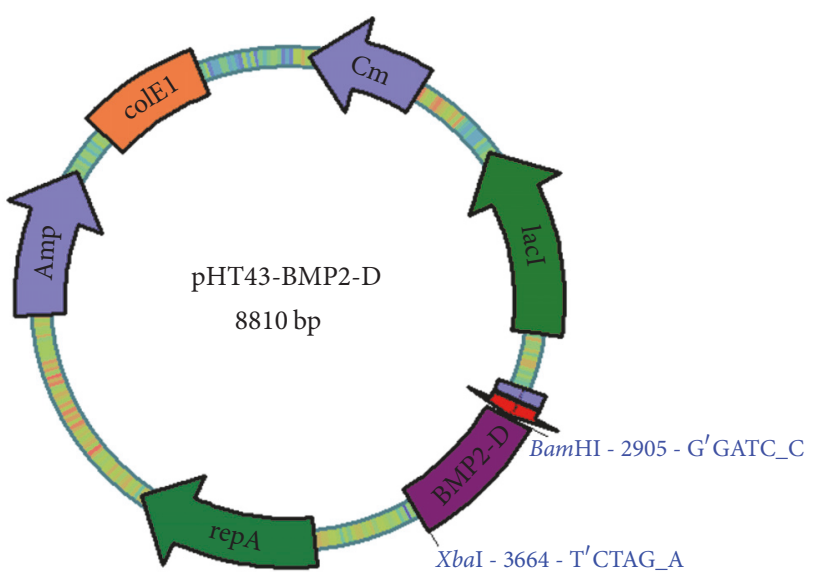

(d)

FIGURE 1: Amplification of BMP2 monomer and dimer and construction of recombinant plasmids. (a) Amplified PCR product of hBMP2 resolved on 1\% agarose gel showing band of BMP2 monomer at 399 bp. Lane M, 1 kb DNA ladder; Lane 1, hBMP2 monomer. (b) Amplified PCR product of hBMP2 dimer showing covalently linked BMP2 dimer at $\sim 780 \mathrm{bp}$. Lane M, $1 \mathrm{~kb}$ DNA ladder; Lane 1, hBMP2 dimer. (c) Recombinant plasmid pHT43-BMP2-M (8429 bp) showing position of the hBMP2 monomer along with restriction sites. (d) Recombinant plasmid pHT43-BMP2-D (8810 bp) showing position of hBMP2 dimer along with restriction sites.

number 10426-HNAE-20) was used at 100 and $500 \mathrm{ng} / \mathrm{ml}$ dose as a positive control and DMEM was used as a negative control. After 72 hours of induction, the cells were washed with 1x PBS and processed for ALP assay. Briefly, the cells were lysed with the assay buffer and the cell lysate was used for the ALP estimation. A standard curve was generated of $p$ NPP $(0,4,8,12,16$, and 20 nmols) substrate of ALP. The quantities of ALP in the test samples were calculated from the standard curve.

\section{Results}

3.1. Construction of BMP2 Monomer and Dimer. The BMP2 monomer was amplified from the already cloned plasmid (pTz57R/BMP2), which encodes the mature peptide of BMP2 that constitutes $\sim 399$ bp [Figure 1(a)]. For the construction of the BMP2 homodimer, BMP2 gene was amplified with two different sets of primers containing a linker sequence. The two monomers were digested and ligated within the linker region by using T4 DNA ligase and amplified to generate homodimer of $\sim 780 \mathrm{bp}$ [Figure 1(b)]. The purified amplicons of BMP2 monomer and dimer were T/A cloned using pTz57R/T vector. Both the monomer and dimer were confirmed with the restriction analysis and further verified and screened for possible mutations by sequencing. The restricted (BamHI/XbaI) and purified BMP2 monomer and dimers were subcloned into the pHT43 vector for the expression study in B. subtilis as shown in Figures 1(c) and 1(d). The secondary cloning was confirmed by the colony PCR and restriction analysis (data not shown). 


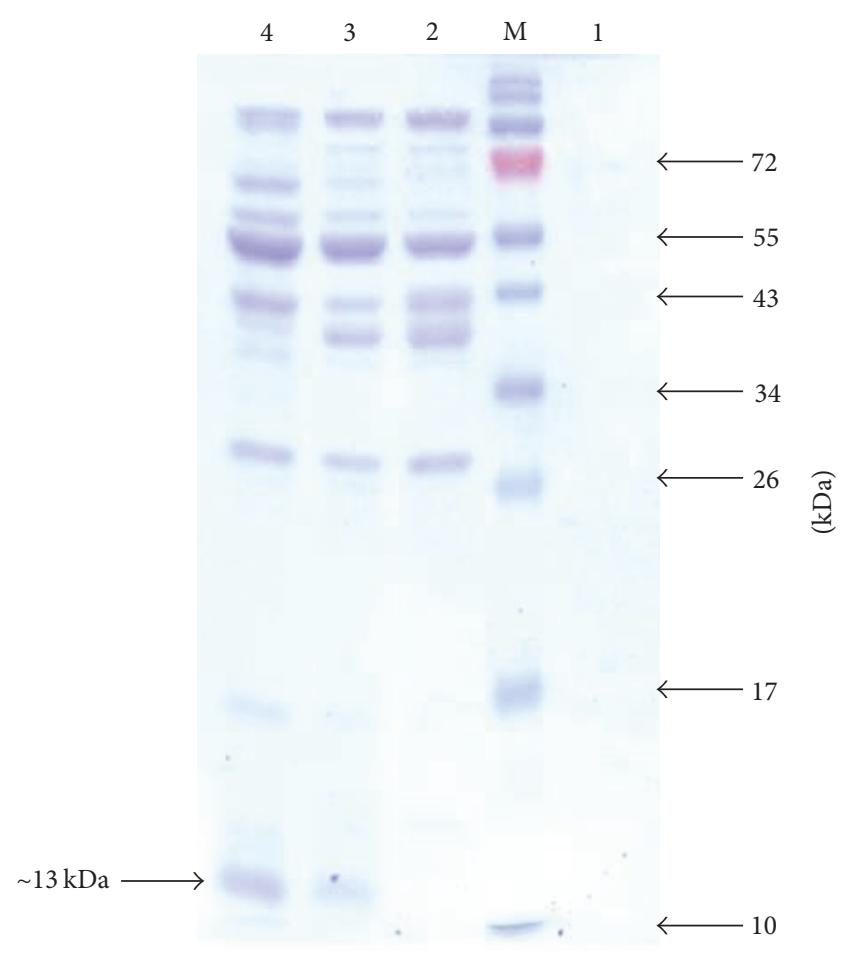

FIGURE 2: Expression of rhBMP2 monomer in 2xYT medium at $37^{\circ} \mathrm{C}$ showing band at $\sim 13 \mathrm{kDa}$. Lane $\mathrm{M}$, protein marker; Lane 1, uninduced sample; Lanes 2-4, showing 2, 4, and 6 hours' postinduction samples.

3.2. Secretory Expression of rhBMP2 in B. subtilis. The initial secretory expression of rhBMP2, using expression vector pHT43-BMP2-M, was confirmed at $37^{\circ} \mathrm{C}$ in $2 \mathrm{xYT}$ medium in SCK6 strain as shown in Figure 2. The rhBMP2 monomer expression was optimized in both strains (SCK6 and WB600) using three different media and at two temperatures, that is, $30^{\circ} \mathrm{C}$ and $37^{\circ} \mathrm{C}$, as mentioned in Materials and Methods. According to the results shown in Figures 3(a) and 3(b) the maximum growth was observed at $37^{\circ} \mathrm{C}$ in $2 \mathrm{xYT}$ media and SCK6 strain as determined by OD600 values, whereas the maximum secretory expression of rhBMP2 monomer ( 35\%) was observed at $30^{\circ} \mathrm{C}$ after 20 hours of fermentation (see Supplementary Figures S1 and S2 in Supplementary Material available online at https://doi.org/10.1155/2017/9350537). However in case of WB600 strain, secretory expression $(\sim 45 \%)$ was observed at only $37^{\circ} \mathrm{C}$ (Supplementary Figure S3) and a very low level of expression was observed at $30^{\circ} \mathrm{C}$ after 24 hours (Supplementary Figure S4) in 2xYT medium, while no expression was visible in LB and 2xL MAL medium (data not shown). The WB600 yielded higher secretory expression at $37^{\circ} \mathrm{C}$ than $\mathrm{SCK} 6$ at $30^{\circ} \mathrm{C}$ in $2 \mathrm{xYT}$ medium but it was not proceeded further due to very high frequency of plasmid instability and early loss of expression. However, to obtain the maximum expression of rhBMP2 dimer, the already optimized conditions in case of rhBMP2 monomer like temperature and media were used. Maximum $25 \%$ of secretory expression of rhBMP2 dimer was achieved at $30^{\circ} \mathrm{C}$ in 2xYT medium in SCK6 strain after 8 hours of fermentation
(Figure 4). IPTG concentration of $0.6 \mathrm{mM}$ was optimized to attain the maximum expression of both rhBMP2 monomer and dimer. However in case of lactose induced expression, rhBMP2 monomer and dimer yielded maximum expression at $6 \mathrm{mM}$ and $10 \mathrm{mM}$, respectively. The fermentation time for rhBMP2 monomer and dimer was optimized at 24 and 16 hours, respectively, by utilizing $10 \mathrm{mM}$ of lactose (data not shown).

3.3. Characterization of rhBMP2. The expression of rhBMP2 monomer and dimer was further confirmed by the western blot analysis. Antibody against the rhBMP2 protein showed two distinct bands at $\sim 13 \mathrm{kDa}$ and $\sim 25 \mathrm{kDa}$ for monomer and dimer, respectively [Figure 5(a)]. The dimeric nature of the BMP2 monomer was confirmed by the native PAGE analysis and showed a distinct band at $\sim 26 \mathrm{kDa}$ [Figure 5(b)]. We did not perform the native PAGE analysis of covalently linked dimer of rhBMP2 due to its size similarity with disulfide linked dimer of BMP2. We hypothesize that the covalently linked dimer of BMP2 is producing dimer of the dimer as it has two cysteine residues available for the disulfide bond formation. This was confirmed by size exclusion chromatography based centrifugal column (Amicon Ultra-15 Centrifugal Filter Units Millipore catalog number UFC905024) with a cut-off value of $50 \mathrm{kDa}$. It showed that all the protein was retained and concentrated on the membrane of the column and nothing was retrieved in the flow through the column which suggested the correctness of our hypothesis [Figure 5(c)].

rhBMP2 monomer and dimer were first purified by using Nickel column due to the incorporation of His-tag at $3^{\prime}$ end of each protein. As a result, all of the rhBMP monomer and dimer were eluted in the flow through. This showed that the His-tag at $3^{\prime}$ end was being masked in both cases of rhBMP monomer and dimer (Supplementary Figure S5). Further to sort out the problem, purification was done by ion exchange chromatography using Hi-Trap Resource Q column (6 ml) using an AKTA Purifier FPLC system. The peaks shown in the chromatogram of the monomer and dimer corresponds to the concentration gradient of $0.9 \mathrm{M}$ and $0.6 \mathrm{M} \mathrm{NaCl}$ solution and the elution volume (Supplementary Figure S6). The fractions were pooled and run on 15\% SDS-PAGE. Approximately 90\% and $80 \%$ purity were achieved in case of rhBMP 2 monomer and dimer, respectively. Final percentage recovery of $1.12 \%$ and $3.17 \%$ for rhBMP2 monomer and dimer, respectively, was achieved (Table 3 ).

The rhBMP2 monomer and dimer were further characterized by their biological activity. The induction of BMP2 on myoblastic and osteoblastic cell lines was reported to stimulate the ALP expression. ALP produced in this reaction was used to hydrolyze the known amount of $p$ NPP which acts as the substrate of ALP. Thus the amount of $p$ NPP hydrolyzed is directly proportional to the amount of ALP produced by the induction of BMP2. Our results showed that the ALP levels were raised in the dose dependent manner of rhBMP2 monomer and dimer as shown in Figure 6. It was observed that at $200 \mathrm{ng} / \mathrm{ml}$ of rhBMP2 monomer and dimer had the maximum activity on $\mathrm{C} 2 \mathrm{C} 12$ cells in vitro, whereas the higher dose $(>400 \mathrm{ng} / \mathrm{ml})$ seems to have an inhibitory 
TABLE 3: Summary of percentage recovery of rhBMP2 monomer and dimer at different steps of production from B. subtilis.

\begin{tabular}{|c|c|c|c|c|c|c|c|c|}
\hline \multirow[b]{2}{*}{$\begin{array}{l}\text { Purification } \\
\text { steps }\end{array}$} & \multicolumn{4}{|c|}{ rhBMP (monomer) } & \multicolumn{4}{|c|}{ rhBMP (dimer) } \\
\hline & $\begin{array}{l}\text { Volume } \\
\text { (ml) }\end{array}$ & $\begin{array}{l}\text { Total protein } \\
(\mathrm{mg})^{\mathrm{a}}\end{array}$ & Purity $(\%)^{\mathrm{b}}$ & Recovery (\%) & Volume (ml) & $\begin{array}{l}\text { Total protein } \\
(\mathrm{mg})^{\mathrm{a}}\end{array}$ & Purity $(\%)^{b}$ & Recovery (\%) \\
\hline $\begin{array}{l}\text { Cultural } \\
\text { supernatant }\end{array}$ & 200 & 90 & 35 & 100 & 200 & 60 & 25 & 100 \\
\hline $\begin{array}{l}\text { Concentrated } \\
\text { by freeze } \\
\text { drying }\end{array}$ & 10 & 89 & 35 & 98 & 5 & 58 & 25 & 96 \\
\hline FPLC & 12 & 1 & 90 & 1.12 & 7 & 1.84 & 80 & 3.17 \\
\hline
\end{tabular}

${ }^{a}$ Protein concentration was determined by absorbance measurements at $\mathrm{OD}_{280} \cdot{ }^{\mathrm{b}}$ The $\%$ age purity was determined by densitometric analysis of $15 \%$ SDS-gel.

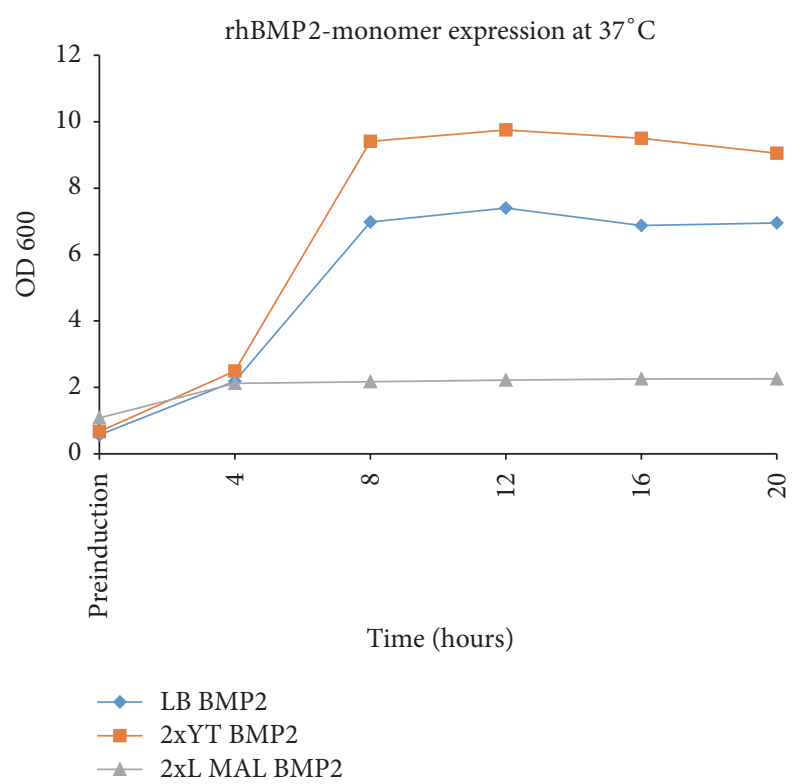

(a)

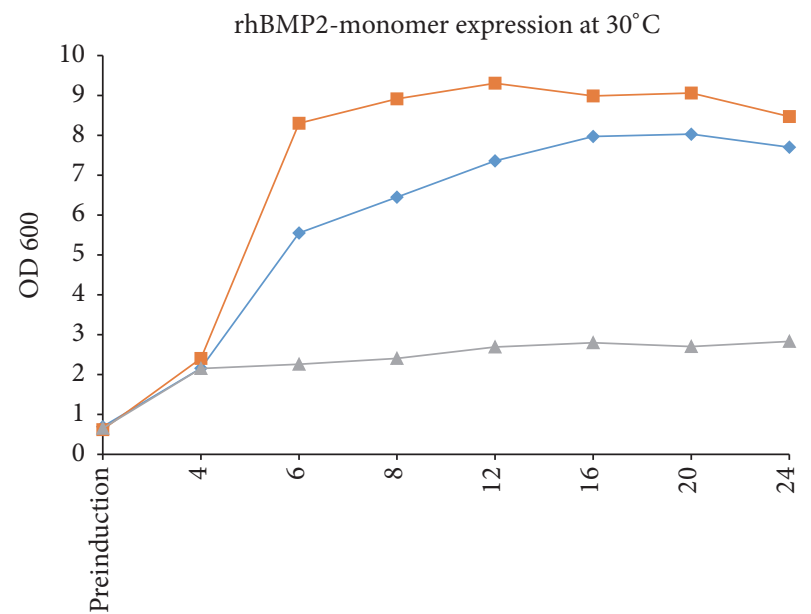

Time (hours)

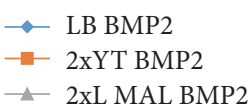

$\rightarrow$ 2xL MAL BMP2

(b)

FIGURE 3: Graphical representation of growth curve of rhBMP2 monomer at $37^{\circ} \mathrm{C}$ and $30^{\circ} \mathrm{C}$ in different media and at different time points. $x$-axis showing the time scale up to 24 hours and $y$-axis showing the absorbance at $600 \mathrm{~nm}$. (a) Growth curve at $37^{\circ} \mathrm{C}$ and maximum growth was observed in $2 \mathrm{xYT}$ medium. (b) Growth curve at $30^{\circ} \mathrm{C}$ in LB, $2 \mathrm{xYT}$, and $2 \mathrm{xL}$ MAL media.

effect as evidenced by the decline in the ALP activity which was further confirmed by the commercially available rhBMP2 positive control as well. However, the negative control, that is, DMEM, showed negligible ALP activity.

\section{Discussion}

The Bacillus secretory expression system was successfully employed for the extracellular secretion of rhBMP2 in dimeric biologically active form. A major limitation of this system is the production of extracellular proteases which degrades the recombinant foreign proteins [24]. In this study two strains were used SCK6 which is genetically modified and has higher competency to uptake foreign DNA molecules and has upregulated expression of ComK gene under the xylose inducible promoter [22]. The other strain was WB600 which is deficient in six extracellular proteases and suitable for the extracellular production of the recombinant proteins [25]. In the current study up to $1 \mathrm{mg}$ and $1.8 \mathrm{mg}$ per $200 \mathrm{ml}$ culture of rhBMP2 monomer and dimer, respectively, were produced successfully.

The BMP2 gene was successfully cloned in monomer and dimeric form into B. subtilis strains SCK6 and WB600. Expression vectors pHT43-BMP2-M and pHT43-BMP2-D contained the Pgrac strong promoter and signal peptide sequence of amyQ ( $\alpha$ amylase) gene of Bacillus amyloliquefaciens which has been reported for the efficient secretion of recombinant proteins through Sec pathway [26]. The final destination of recombinant proteins depends on the presence or absence of signal peptide which serves as the global positioning system; any protein produced without signal peptide is retained in the cytoplasm [27]. In Sec dependent secretory pathway, proteins produced as preprotein complex with an $\mathrm{N}$-terminal signal peptide translocate to the cell 


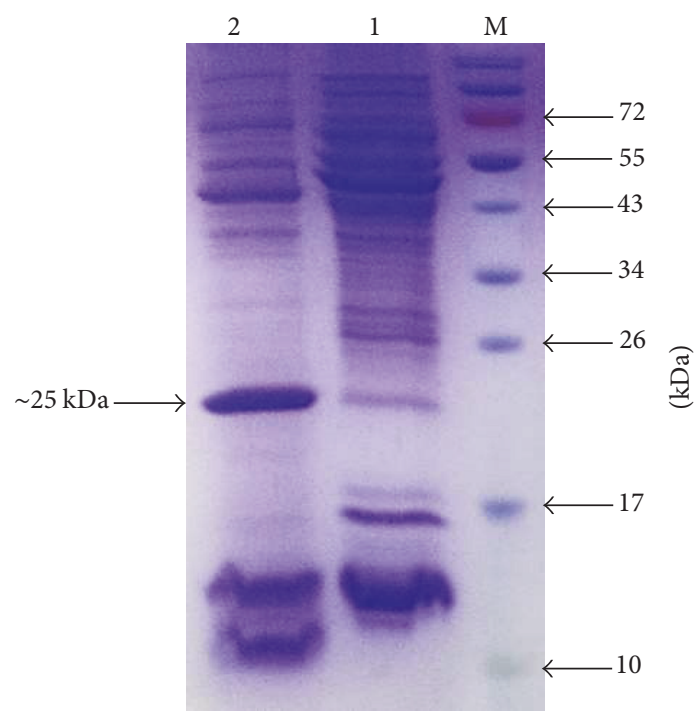

FIgUre 4: Expression of rhBMP2 dimer in $2 \mathrm{xYT}$ medium at $30^{\circ} \mathrm{C}$. Lane M, protein marker; Lane 1, uninduced sample; Lane 2, rhBMP2 dimer induced with IPTG showing band at $\sim 25 \mathrm{kDa}$.

membrane where it binds to the secretory translocase complex recognized by the signal peptide. Protein is transported out of the cell after the removal of signal peptide at the cleavage site by specific signal peptidase [28, 29]. Thus, the selection of suitable signal peptide affects the rate of protein secretion and ultimately the yield of the secreted protein. One of the choices to select the signal peptide is the usage of commercially available signal peptides, literature survey, and review of proteome of the host organism for signal peptide. The latter is linked to the high yield of the homologous secreted proteins $[11,27]$. In this study we have used the signal peptide of $\alpha$-amylase which has been reported for high secretion of homologous protein and have well defined cleavage site. Moreover, its usage is also reported for heterologous proteins, for example, extracellular secretion of human proteins including IL-3 and interferon $\alpha 2$ (INF $\alpha 2$ ) $[16,20]$.

Generally bacterial expression systems are unable to produce proteins in dimeric form and it is reported previously that rhBMP2 produced from $E$. coli was in an inactive and monomeric form $[9,30]$. To overcome this problem a covalently linked homodimer of rhBMP2 consisting of glycine serine rich linker between two monomers of BMP2 was generated. This strategy had been reported previously in the case of heterodimers BMP2/BMP7 and some other proteins of BMP family and proved to be useful in the generation of active heterodimers [31]. In this study we have successfully generated the active form of homodimer with total $25 \%$ of the secretory expression. However, the maximum secretory expression of the monomer was obtained to be $35 \%$. Interestingly, WB600 cells showed high protein expression at $37^{\circ} \mathrm{C}$ as compared to SCK6 but with the limitation of plasmid instability. Previous data reports that plasmid instability is not a rare phenomenon in B. subtilis [11, 24]. The plasmid instability is either segregational or structural; the segregational instability is more common in plasmids with low copy number, while the structural instability is difficult to detect with conventional selection pressure [32]. However, we did not face any such problem in SCK6 strain. Extracellular proteases are another major limitation of the Bacillus secretory expression system and among all the Bacillus strains, WB600 is deficient in six extracellular proteases which makes it suitable host for the production of secretory proteins. However, these protease deficient strains are more prone to cell lysis and ultimately reduce the growth which in turn leads to plasmid instability [33]. In our study the loss of expression in WB600 could also be due to secretion stress as the vector used in this study was of high copy number and large amount of protein accumulation in the pseudo (periplasmic) membrane can often lead to reduced growth and even cell death [28]. The hypothesis of secretion stress as the cause of expression loss was established on the observation that plasmid pHT43 contained ColE1 origin of replication which is associated with relaxed type of replication control and high copy number [34]. Furthermore, the presence of repA protein ensures the theta mode of replication which is derived from the naturally isolated pTB19 and pAM $\beta 1$ larger plasmids of Bacillus specie [26]. Moreover, repA replication region shares no sequence homology with the rolling circle replication regions which is highly conserved in smaller plasmids and does not lead to the accumulation of ssDNA $[35,36]$, thus preventing the structural instability of the plasmid. Further the high initial expression of rhBMP2 in WB600 even at low cell density strengthens our hypothesis of secretion stress due to high copy number and greater metabolic stress. Although this is beyond the context of the current study to rule out the exact cause, it opens the door for the future.

Generally the yield of the secreted proteins is less as compared to the intracellular proteins. B. subtilis has been reported to secrete large quantities of enzymes into the culture medium mainly the extracellular proteases. Previous studies report that the homologous industrial enzymes like proteases were produced up to grams/L by B. subtilis $[11,23]$. But the production and secretion of heterologous proteins are not that straightforward. Previous studies on recombinant production of human proteins from $B$. subtilis reported varying levels of secretory yield from as low as $100 \mu \mathrm{g}$ in case of IL3 to $1000 \mathrm{mg}$ in case of proinsulin. It is important to note that all those studies (Table 1) deployed different sets of conditions including vectors used with different signal peptide and different composition of media [16-21]. Specifically to BMP family, only BMP7 had been produced in B. subtilis other than rhBMP2 which was produced in the current study. The difference resides among the signal peptide, vector, and medium used; pLip signal peptide under the control of HpaII promoter was used in BMP7 production in LBL (Luria Broth + Lactose) medium [15] whereas we have used amyQ signal sequence under Pgrac promoter control with 2x YT medium. At least, in context of BMP family we have shown that our optimized conditions provided improved extracellular production of the rhBMP2. Other proteins including IL-3, IL-2, GCSF, Epidermal Growth factor (EGF), INF $\alpha 2$, and proinsulin had been produced with different set of conditions but the overall yield is considerably low as compared to 


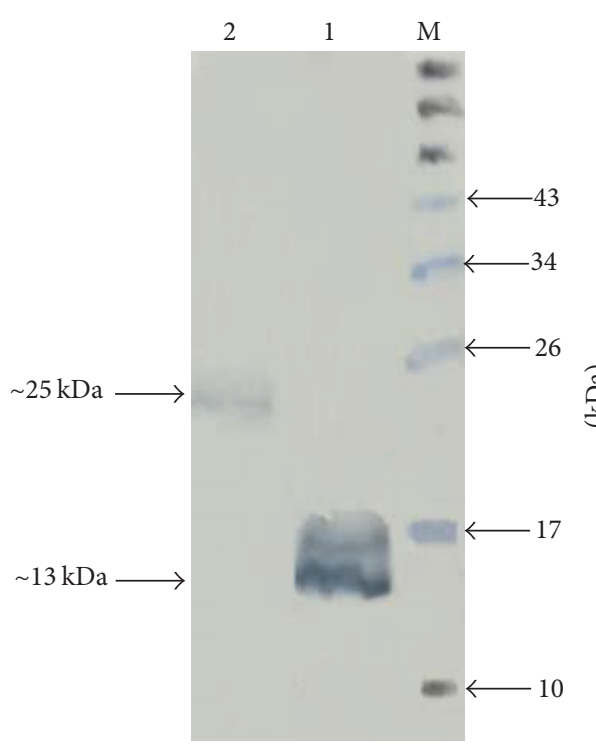

(a)

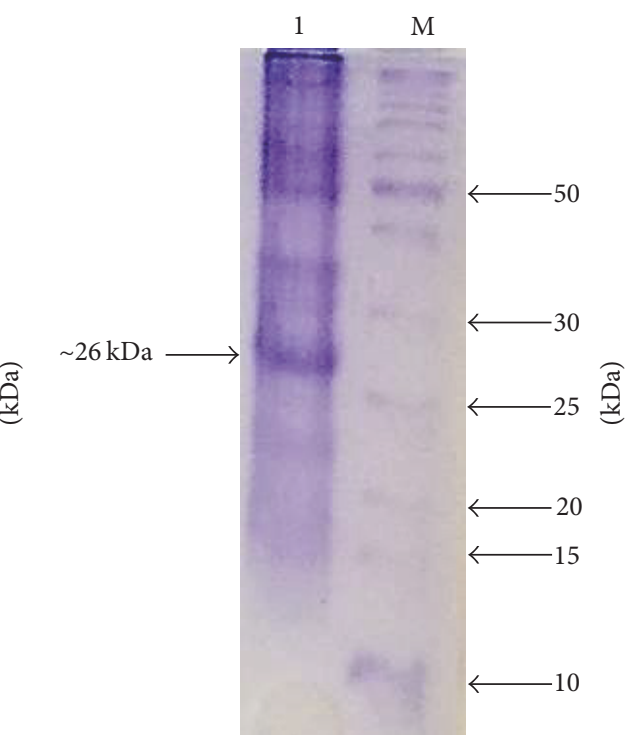

(b)

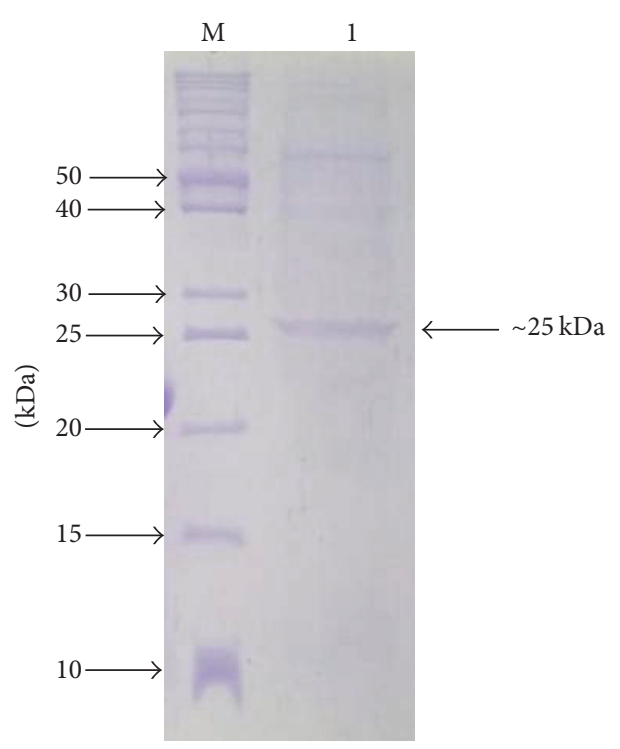

(c)

FIgURE 5: Characterization of rhBMP2 monomer and dimer. (a) Western blot analysis of rhBMP2 monomer and dimer. Lane M, protein marker; Lane 1, rhBMP2 monomer showing band at $\sim 13 \mathrm{kDa}$; Lane 2, rhBMP2 dimer showing band at $\sim 25 \mathrm{kDa}$. (b) Native PAGE analysis of rhBMP2 monomer showing dimerized form. Lane M, protein marker; Lane 1, nonreducing rhBMP2 monomer showing band at $26 \mathrm{kDa}$. The band is slightly above the $26 \mathrm{kDa}$ marker band due to nonreducing nature of the sample. (c) $18 \%$ SDS-PAGE showing band of rhBMP2 dimer at $\sim 25 \mathrm{kDa}$ after collecting supernatant from $50 \mathrm{kDa}$ Amicon Ultra centrifugal column.

E. coli system [15-18]. Previously Westers et al. have tested different sets of promoters and signal peptides along with three different types of media for IL-3 production [16]. They have reported a gross increase in yield from $100 \mu \mathrm{g}$ to $100 \mathrm{mg} / \mathrm{L}$ by changing the combination of promoter and signal peptide. According to them the best combination was the use of $\alpha$ amylase signal peptide with pHT43 promoter, which resulted in the maximum secretion of IL-3 protein and near zero cytoplasmic retention. These findings had also confirmed our use of amyQ signal peptide for efficient secretion. Although they also have encountered the loss of expression in protease deficient strain (WB700), in this study we achieved $5 \mathrm{mg} / \mathrm{L}$ in case of rhBMP 2 monomer and $9 \mathrm{mg} / \mathrm{L}$ in case of rhBMP2 dimer with the percentage purity of $90 \%$ and $80 \%$, respectively. However, Kim et al. reported that BMP7 was produced in the concentration of $0.8 \mu \mathrm{g}$ from a $3 \mathrm{~L}$ culture with the recovery of $58.5 \%$ and purity of $57.1 \%$, respectively. We have achieved the final yield and purity greater than the BMP7 by Kim et al. [15]. The low yield of the heterologous proteins makes it difficult to purify with sufficient high recovery. Generally multiple steps are required to achieve a considerable amount of percentage purity. First the 


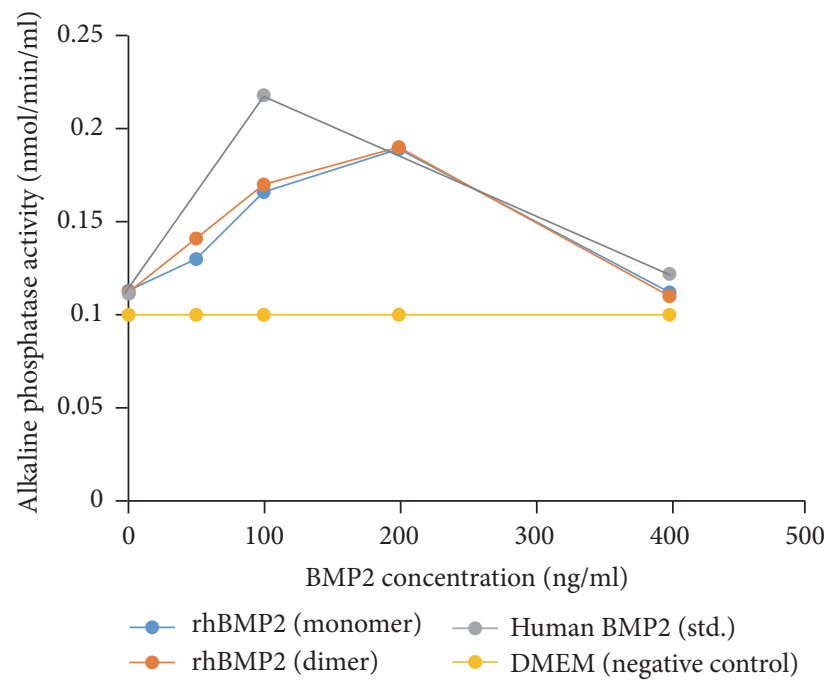

Figure 6: Biological activity of rhBMP2 monomer and dimer estimated by ALP assay and measured at $\mathrm{nmol} / \mathrm{ml} / \mathrm{min}$. (a) Standard curve of ALP. $x$-axis showing the $p \mathrm{NPP}$ conc. (nmol) and $y$-axis showing the absorbance at $405 \mathrm{~nm}$. (b) Different concentrations of rhBMP2 monomer and dimer $(0,50,100,200$, and $400 \mathrm{ng} / \mathrm{ml})$ were tested and maximum activity was observed at $200 \mathrm{ng} / \mathrm{ml}$, respectively, in dose dependent manner. Higher dose $(400 \mathrm{ng} / \mathrm{ml})$ showed reduce activity. Positive control (human BMP standard) was tested at 100 and $500 \mathrm{ng} / \mathrm{ml}$ doses and showed reduce activity at $500 \mathrm{ng} / \mathrm{ml}$. Negative control (DMEM) showed negligible ALP activity.

proteins have to be concentrated in the culture supernatant. We have freeze dried the proteins to reduce the volume of the culture supernatant to make it sufficiently low for the FPLC purification system. Then the protein was dialyzed through a suitable size of dialysis membrane $(6-8 \mathrm{kDa})$ for the exchange of buffer and followed by a column purification step and at the end an additional step of size exclusion or gel filtration to achieve the maximum purity.

Previously in case of the BMP7, IL-2, IL-3, EGF, INF $\alpha 2$, proinsulin, and GCSF as well as in our study all the proteins produced by the Bacillus expression system were biologically active and in proper refolded configuration. This might be due to the presence of the molecular chaperons which aid in the refolding of the proteins and presence of the oxidoreductases which help in disulfide bond formation and dimer generation [11,33]. Although it has an advantage of proper refolding and soluble and dimeric protein production the labor intensive purification process and the low yields make it unsuitable expression system for the production of mammalian proteins and especially of the BMP family.

\section{Conclusions}

In conclusion, we have successfully produced dimerized bioactive rhBMP2 as secretory protein from $B$. subtilis system. Furthermore, the covalently linked homodimer of rhBMP2 was also produced in tetramer conformation along with the dimeric configuration. Further improvement in terms of protein yield and secretion can be done by optimizing media and the combination of signal peptide along with promoter. But special focus is required in selecting the vector as very high copy number of the vector can lead to secretion stress which ultimately leads to expression loss. Also for the heterologous proteins, the optimization strategy and the expression level varies dramatically from protein to protein and cannot be generalized.

$\begin{array}{ll}\text { Abbreviations } \\ \text { ALP: } & \text { Alkaline phosphatase } \\ \text { amyQ: } & \alpha \text {-Amylase } \\ \text { B. subtilis: } & \text { Bacillus subtilis } \\ \text { BMP: } & \text { Bone Morphogenetic Protein } \\ \text { DMEM: } & \text { Dulbecco's Modified Eagle Medium } \\ \text { E. coli: } & \text { Escherichia coli } \\ \text { FBS: } & \text { Fetal Bovine Serum } \\ \text { FPLC: } & \text { Fast Protein Liquid Chromatography } \\ \text { GRAS: } & \text { Generally Recognized as Safe } \\ \text { GCSF: } & \text { Granulocyte Colony Stimulating Factor } \\ \text { hBMP: } & \text { human Bone Morphogenetic Protein } \\ \text { IPTG: } & \text { Isopropyl } \beta \text {-D-1-thiogalactopyranoside } \\ \text { IL-2: } & \text { Interleukin 2 } \\ \text { IL-3: } & \text { Interleukin } 3 \\ \text { PAGE: } & \text { Polyacrylamide Gel Electrophoresis } \\ \text { pNPP: } & \text { para-Nitrophenylphosphate } \\ \text { rhBMP: } & \text { Recombinant human Bone } \\ & \text { Morphogenetic Protein } \\ \text { SDS-PAGE: } & \text { Sodium Dodecyl Sulfate Polyacrylamide } \\ & \text { Gel Electrophoresis } \\ \text { TCA: } & \text { Trichloroacetic acid } \\ \text { TGF } \beta: & \text { Transforming Growth Factor beta } \\ \text { TMB: } & \text { 3,3',5,5'-Tetramethylbenzidine. } \\ & \end{array}$

\section{Conflicts of Interest}

All the authors of the manuscript declare no scientific and financial conflicts of interest.

\section{Authors' Contributions}

Muhammad Umair Hanif participated in designing the study, carried out all the experiments, complied and interpreted the data, and drafted the manuscript. Roquyya Gul managed the whole research project as Principal Investigator and supported in drafting and also helped in the final revision of the manuscript. Muhammad Imran Hanif coordinated the laboratory activity and assisted in the experiments. Abid Ali Hashmi facilitated in providing all kinds of instrumental access and management. The authors have read and approved the final version of the manuscript.

\section{Acknowledgments}

The authors highly acknowledge Dr. Muhammad Waheed Akhtar, Director of School of Biological Sciences, and his squad from University of the Punjab, Lahore, for their immense support and guidance in characterization of the rhBMP2. The funding source to conduct the research and 
laboratory facilities were supported by the Gulab Devi Educational Complex, Lahore, Pakistan.

\section{References}

[1] A. C. Carreira, F. H. Lojudice, E. Halcsik, R. D. Navarro, M. C. Sogayar, and J. M. Granjeiro, "Bone morphogenetic proteins: facts, challenges, and future perspectives," Journal of Dental Research, vol. 93, no. 4, pp. 335-345, 2014.

[2] D. Chen, M. Zhao, and G. R. Mundy, "Bone morphogenetic proteins," Growth Factors, vol. 22, no. 4, pp. 233-241, 2004.

[3] Q. Wu, C. C. Sun, H. Y. Lin, and J. L. Babitt, "Repulsive Guidance Molecule (RGM) Family Proteins Exhibit Differential Binding Kinetics for Bone Morphogenetic Proteins (BMPs)," PLoS ONE, vol. 7, no. 9, Article ID e46307, 2012.

[4] K. A. Hussein, I. E. Zakhary, D. Hailat, R. Elrefai, M. Sharawy, and M. E. Elsalanty, "Delayed versus immediate reconstruction of mandibular segmental defects using recombinant human bone morphogenetic protein 2/absorbable collagen sponge," Journal of Oral and Maxillofacial Surgery, vol. 71, no. 6, pp. 11071118, 2013.

[5] J. G. Devine, J. R. Dettori, J. C. France, E. Brodt, and R. A. McGuire, "The use of rhBMP in spine surgery: is there a cancer risk?” Evidence-Based Spine-Care Journal, vol. 3, no. 2, pp. 3541, 2012.

[6] N. R. Kübler, J. F. Reuther, G. Faller, T. Kirchner, R. Ruppert, and W. Sebald, "Inductive properties of recombinant human BMP2 produced in a bacterial expression system," International Journal of Oral and Maxillofacial Surgery, vol. 27, no. 4, pp. 305309, 1998.

[7] W. D. Fairlie, H.-P. Zhang, P. K. Brown, P. K. Russell, A. R. Bauskin, and S. N. Breit, "Expression of a TGF- $\beta$ superfamily protein, macrophage inhibitory cytokine-1, in the yeast Pichia pastoris," Gene, vol. 254, no. 1-2, pp. 67-76, 2000.

[8] P. Doolan, M. Melville, P. Gammell et al., "Transcriptional profiling of gene expression changes in a PACE-transfected $\mathrm{CHO}$ DUKX cell line secreting high levels of rhBMP-2," Molecular Biotechnology, vol. 39, no. 3, pp. 187-199, 2008.

[9] A. L. Demain and P. Vaishnav, "Production of recombinant proteins by microbes and higher organisms," Biotechnology Advances, vol. 27, no. 3, pp. 297-306, 2009.

[10] J. Chen, G. Fu, Y. Gai, P. Zheng, D. Zhang, and J. Wen, "Combinatorial Sec pathway analysis for improved heterologous protein secretion in Bacillus subtilis: Identification of bottlenecks by systematic gene overexpression," Microbial Cell Factories, vol. 14, no. 1, article 92, 2015.

[11] R. Nijland and O. P. Kuipers, "Optimization of protein secretion by Bacillus subtilis," Recent Patents on Biotechnology, vol. 2, no. 2, pp. 79-87, 2008.

[12] E. Ferrari, A. S. Jarnagin, and B. F. Schmidt, "Commercial production of extracellular enzymes," in Bacillus Subtilis and Other Gram-Positive Bacteria, pp. 917-937, American Society of Microbiology, 1993.

[13] M. Schallmey, A. Singh, and O. P. Ward, "Developments in the use of Bacillus species for industrial production," Canadian Journal of Microbiology, vol. 50, no. 1, pp. 1-17, 2004.

[14] M. Simonen and I. Palva, "Protein secretion in Bacillus species," Microbiology and Molecular Biology Reviews, vol. 57, no. 1, pp. 109-137, 1993.
[15] C.-K. Kim, S.-D. Oh, J. I. Rhee, E. M. Lee, and T.-R. Yoon, "Expression and purification of recombinant human bone morphogenetic protein-7 (rhBMP-7) in Bacillus subtilis," Biotechnology and Bioprocess Engineering, vol. 15, no. 5, pp. 830-836, 2010.

[16] L. Westers, D. S. Dijkstra, H. Westers, J. M. van Dijl, and W. J. Quax, "Secretion of functional human interleukin-3 from Bacillus subtilis," Journal of Biotechnology, vol. 123, no. 2, pp. 211-224, 2006.

[17] Y. Takimura, M. Kato, T. Orta, H. Yamagata, and S. Udaka, "Secretion of human interleukin-2 in biologically active form by bacillus brevis directly into cultute medium," Bioscience, Biotechnology, and Biochemistry, vol. 61, no. 11, pp. 1858-1861, 1997.

[18] S. Bashir, S. Sadaf, S. Ahmad, and M. W. Akhtar, "Enhanced and secretory expression of human granulocyte colony stimulating factor by bacillus subtilis sck6," BioMed Research International, vol. 2015, Article ID 636249, 9 pages, 2015.

[19] K. H. E. Lam, K. C. Chow, and W. K. R. Wong, "Construction of an efficient Bacillus subtilis system for extracellular production of heterologous proteins," Journal of Biotechnology, vol. 63, no. 3, pp. 167-177, 1998.

[20] I. Palva, P. Lehtovaara, L. Kääriäinen et al., "Secretion of Interferon by Bacillus subtilis," Gene, vol. 22, no. 2-3, pp. 229-235, 1983.

[21] J. Olmos-Soto and R. Contreras-Flores, "Genetic system constructed to overproduce and secrete proinsulin in Bacillus subtilis," Applied Microbiology and Biotechnology, vol. 62, no. 4, pp. 369-373, 2003.

[22] X.-Z. Zhang and Y.-H. P. Zhang, "Simple, fast and highefficiency transformation system for directed evolution of cellulase in Bacillus subtilis," Microbial Biotechnology, vol. 4, no. 1, pp. 98-105, 2011.

[23] C. Heng, Z. Chen, L. Du, and F. Lu, "Expression and secretion of an acid-stable $\alpha$-amylase gene in Bacillus subtilis by SacB promoter and signal peptide," Biotechnology Letters, vol. 27, no. 21, pp. 1731-1737, 2005.

[24] A. Bolhuis, H. Tjalsma, H. E. Smith et al., "Evaluation of bottlenecks in the late stages of protein secretion in Bacillus subtilis," Applied and Environmental Microbiology, vol. 65, no. 7, pp. 2934-2941, 1999.

[25] X.-C. Wu, W. Lee, L. Tran, and S.-L. Wong, "Engineering a Bacillus subtilis expression-secretion system with a strain deficient in six extracellular proteases," Journal of Bacteriology, vol. 173, no. 16, pp. 4952-4958, 1991.

[26] T. T. P. Phan, H. D. Nguyen, and W. Schumann, "Novel plasmidbased expression vectors for intra- and extracellular production of recombinant proteins in Bacillus subtilis," Protein Expression and Purification, vol. 46, no. 2, pp. 189-195, 2006.

[27] K. O. Low, N. M. Mahadi, and R. M. Illias, "Optimisation of signal peptide for recombinant protein secretion in bacterial hosts," Applied Microbiology and Biotechnology, vol. 97, no. 9, pp. 3811-3826, 2013.

[28] M. Sarvas, C. R. Harwood, S. Bron, and J. M. Van Dijl, "Posttranslocational folding of secretory proteins in Gram-positive bacteria," Biochimica et Biophysica Acta (BBA) - Molecular Cell Research, vol. 1694, no. 1-3, pp. 311-327, 2004.

[29] L. L. Fu, Z. R. Xu, W. F. Li, J. B. Shuai, P. Lu, and C. X. Hu, "Protein secretion pathways in Bacillus subtilis: implication for optimization of heterologous protein secretion," Biotechnology Advances, vol. 25, no. 1, pp. 1-12, 2007. 
[30] H. G. Schmoekel, F. E. Weber, J. C. Schense, K. W. Gratz, P. Schawalder, and J. A. Hubbell, "Bone repair with a form of BMP2 engineered for incorporation into fibrin cell ingrowth matrices," Biotechnology and Bioengineering, vol. 89, pp. 253-262, 2005.

[31] W. Zhu, J. Kim, C. Cheng et al., "Noggin regulation of bone morphogenetic protein (BMP) $2 / 7$ heterodimer activity in vitro," Bone, vol. 39, no. 1, pp. 61-71, 2006.

[32] L. A. Palomares, S. Estrada-Mondaca, and O. T. Ramirez, "Production of recombinant proteins: challenges and solutions," Methods in Molecular Biology, vol. 267, pp. 15-52, 2004.

[33] L. Westers, H. Westers, and W. J. Quax, "Bacillus subtilis as cell factory for pharmaceutical proteins: a biotechnological approach to optimize the host organism," Biochimica et Biophysica Acta (BBA) - Molecular Cell Research, vol. 1694, no. 1-3, pp. 299-310, 2004.

[34] G. Cesareni, M. Helmer-Citterich, and L. Castagnoli, "Control of ColE1 plasmid replication by antisense RNA," Trends in Genetics, vol. 7, no. 7, pp. 230-235, 1991.

[35] M. A. Titok, J. Chapuis, Y. V. Selezneva et al., "Bacillus subtilis soil isolates: Plasmid replicon analysis and construction of a new theta-replicating vector," Plasmid, vol. 49, no. 1, pp. 53-62, 2003.

[36] L. Jannière, C. Bruand, and S. Dusko Ehrlich, "Structurally stable Bacillus subtilis cloning vectors," Gene, vol. 87, no. 1, pp. 5361, 1990. 

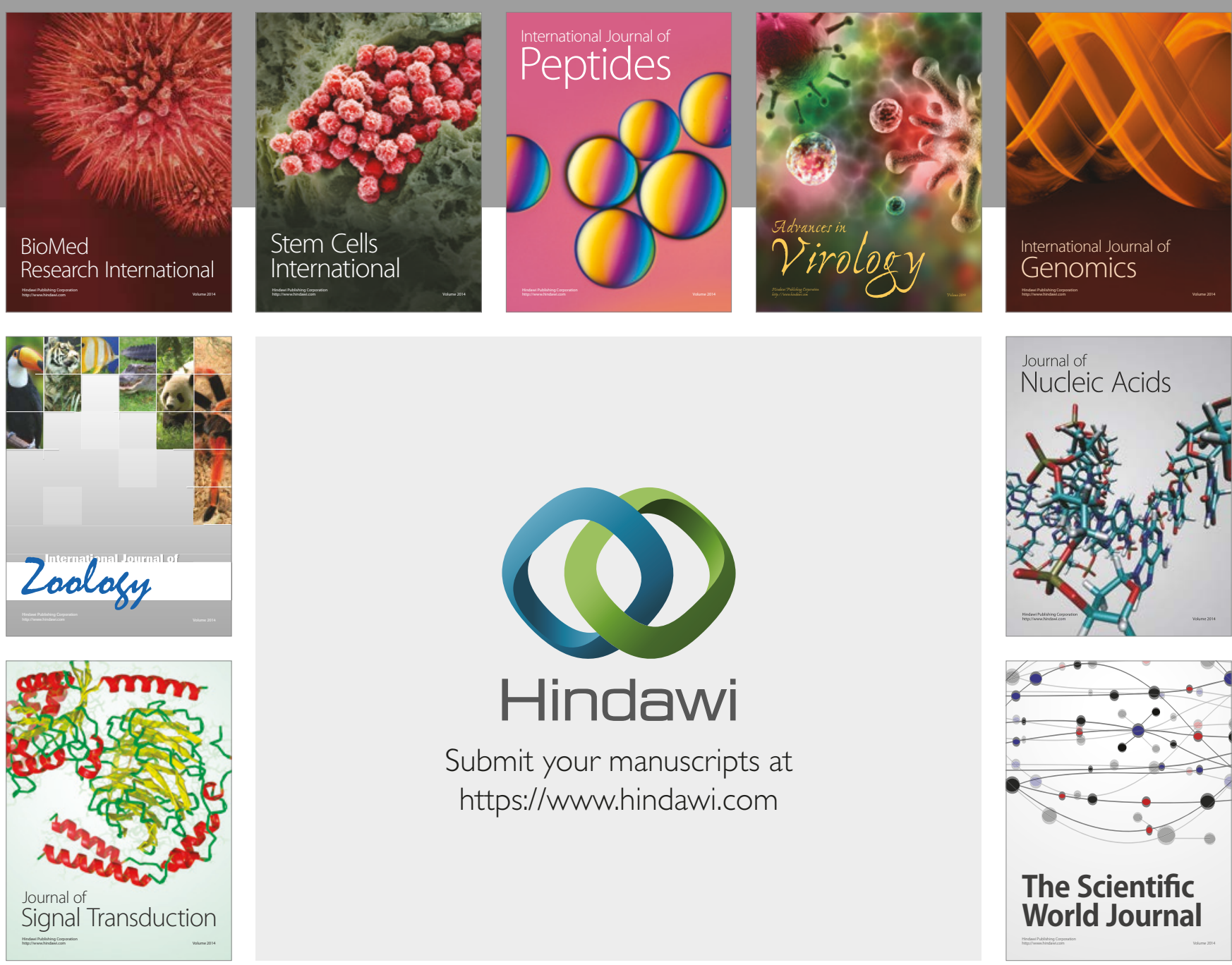

Submit your manuscripts at

https://www.hindawi.com
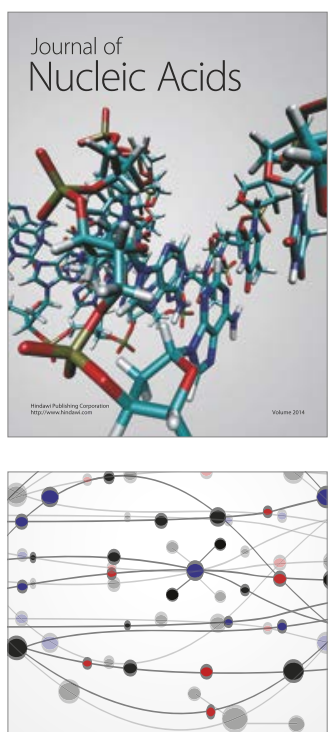

The Scientific World Journal

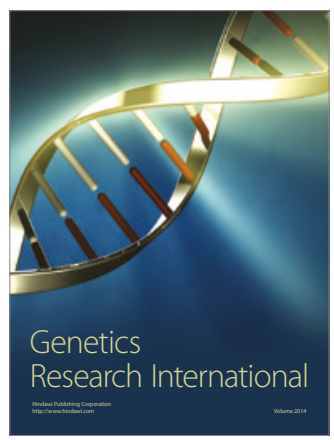

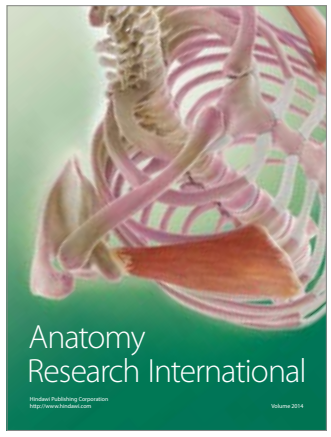

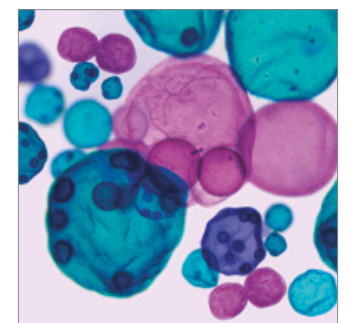

International Journal of Microbiology
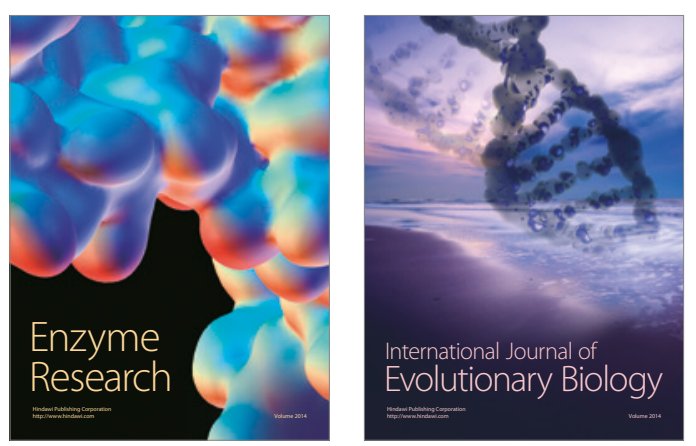
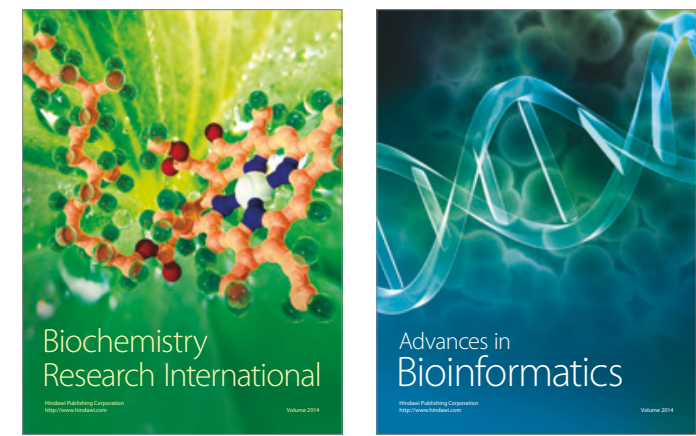

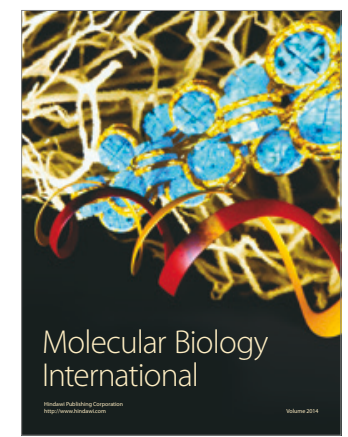

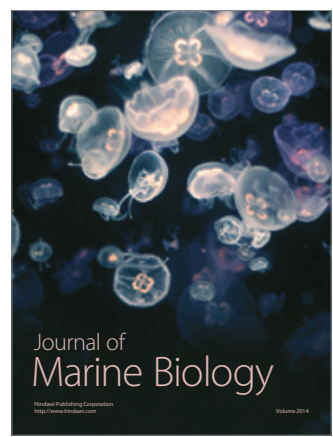

